\title{
STADIUM TURNAMEN E-SPORT DI JAKARTA
}

\author{
Brian Martin $^{1)}$, Dewi Ratnaningrum ${ }^{2)}$ \\ 1) Program Studi S1 Arsitektur, Fakultas Teknik, Universitas Tarumanagara, Pretty_08_angel@yahoo.com \\ 2) Program Studi S1 Arsitektur, Fakultas Teknik, Universitas Tarumanagara, dewir@ft.untar.ac.id
}

\begin{abstract}
Abstrak
Jakarta merupakan sebuah kota metropolis yang menjadi sebuah tempat / pusat perekonomian dan dengan jumlah kepadatan penduduk yang sangat tinggi yang pastinya juga membuat aktivitas di kota ini berjalan dengan sangat cepat. Hal ini berdampak pada tingkat stress yang cukup tinggi dan di alami oleh hampir semua orang yang tinggal dan beraktivitas dengan frekuensi yang cukup tinggi di kota Jakarta. Oleh karna itu, membutuhkan sebuah wadah tempat rekreasi yang baru di tengah - tengah tempat rekreasi yang sudah ada di kota Jakarta ini khususnya untuk tempat bermain dengan teknologi yang tengah berkembang saat ini namun masih belum memiliki wadah khusus. Tempat bermain dengan teknologi yang tengah berkembang saat ini salah satunya ialah E-sport. E-sport ini sendiri adalah sebuah jenis permainan yang tengah sangat berkembang di seluruh penjuru dunia dan juga tentunya di Indonesia juga, namun belum memiliki sebuah wadah yang khusus untuk kita bisa menikmati bersama E-sport itu, khususnya di kota Jakarta yang sangat padat ini. E-Sport ini sendiri menunjukan perkembangan yang sangat pesat di Indonesia. Salah satunya adalah cabang E-sport yang di perlombakan pada ajang Asean Games 2018. Untuk itu penulis mengkaji dan menganalisis tentang E-sport ini sendiri untuk dapat merancang sebuah wadah E-sport yang belum ada di Jakarta. Selain dapat menjadi sebuah wadah baru, tempat berwisata yang fresh, dan juga bisa menjadi salah satu ladang baru untuk mencari nafkah yang dapat di lakukan oleh semua kalangan dan umur dari anak anak hingga orang tua.
\end{abstract}

Kata kunci: kota Jakarta, metropolis, wisata rekreasi

\begin{abstract}
Jakarta is a metropolis which is the center of the city and a very high population must also make activities in this city run very fast. This has an impact on the level of stress that is quite high and natural by inhibiting all people who live and move with a high enough frequency in the city of Jakarta. Because of that, this new place of recreation in the middle of a recreational place that already exists in Jakarta requires a place to play with technology that is currently developing, but still does not have a special container. A place to play with developing technology Currently one of them is E-sport. E-sport itself is a type of game that is highly developed in all corners of the world and can also be in Indonesia too, but does not yet have a special container for us to enjoy with E-sport, especially in this very crowded city of Jakarta.E-Sport itself shows a very fast development in Indonesia, one of which is an E-sport branch which is contested at the 2018 Asean Games. For this reason, the author reviews and analyzes the E-sport itself to be able to provide E-sport containers that do not yet exist, specifically in Jakarta. Besides being able to become a new container, a fresh tourist spot, and also can be a new place to make a living that can be done by all ages and ages from children to the elderly.
\end{abstract}

Keywords E-sport, Jakarta city, metropolitan city, recreational tourism 


\section{PENDAHULUAN Latar Belakang}

Perkembangan dunia di tengah era moderenisasi ini tak lepas hubungannya dengan penggunaan internet. Begitupun di Indonesia, khususnya di Jakarta yang juga terkena efek dari era modern ini. Menurut lembaga riset pasar e-Marketer, populasi pengguna internet Tanah Air yang mencapai 83,7 juta orang pada 2014. Kemudian Pada 2017, e-Marketer memperkirakan bakal mencapai 112 juta orang, mengalahkan Jepang di peringkat ke-5 yang pertumbuhan jumlah pengguna internetnya tergolong lebih lambat. Berdasarkan tingakatan tersebut, penggunaan internet di Indonesia berada pada urutan 6 teratas di dunia dalam hal penggunaan internet.

Berdasarkan data - data yang ada. Perkembangan di era modern ini juga membawa sebuah dampak yang besar serta peluang baru pada sektor wisata rekreasi. Karena tingkat pengguna internet di Indonesia sangat tinggi dan khususnya di Jakartapun paling tinggi di bandingkan dengan daerah lainnya, mengingat Jakarta adalah kota metropolitan yang sungguh memerlukan wisata rekreasi yang fresh demi menunjang perkembangan yang ada, yaitu salah satunya wisata rekreasi olahraga non fisik (e-sport). Wisata rekreasi E-sport ini sendiri jika dari dulu indentik dengan penggunaan komputer yang hanya bisa di akses / di nikmati oleh kalangan menengah ke atas. Namun seiring berkembangnya jaman, kini game - game yang sudah masuk e-sport juga bisa di akses / dimainkan melalui hp yang dimana untuk sekarang ini e-sport bs di lakukan dengan hp dan di peruntukan untuk semua kalangan. Dampak dari hal tersebut ialah melonjaknya keuntungan para developer games khususnya game mobile. Selain lonjakan dari data jumlah pemasangan aplikasi yang didapat, Indonesia juga mengalami peningkatan dari segi pendapatan per pengguna. Rata-rata pendapatan yang dapat diperoleh dari tiap gamer mobile yang berada di Indonesia saat ini memiliki angka pertumbuhan yang mencapai tujuh persen, hampir serupa dengan India.

Berdasarkan pada SuperData, persentase konsumen game mobileyang berbayar di Indonesia hampir lima puluh persen lebih tinggi disbanding dengan India, dan cenderung membeli hampir dua kali lipat lebih banyak dari pada konsumen normal. Dari gambaran tersebut memang sangat menarik bila melakukan bisnis aplikasi dangame mobile. Perkembangan yang baik ini tak hanya terjadi pada platform mobile saja, tetapi juga berlaku bagi industri kreatif secara umum. Menurut prediksi Badan Ekonomi Kreatif Indonesia, seperti dikutip dari Detik, nilai pasar game di Indonesia mengalami sebuah peningkatan yang cukup pesat dari tahun ke tahun. Pada tahun 2016, pasar game Indonesia diperkirakan hampir menembus angka US\$700 juta (sekitar Rp9,3 triliun). Angka ini diperkirankan akan semakin meningkat tiap tahun.

E-sports sendiri setiap tahunnya memiliki perkembangan yang sangat pesat dan dari keseluruhan para penggemar dan penonton E-sports itu sendiri, 54\% nya berasal dari Asia. Pengertian dari E-sports itu sendiri adalah aktifitas rekreasi ketangkasan yang dilakukan individu maupun berkelompok yang saling bertanding satu dengan lainnya baik fisik dan non fisik yang menggunakan alat yang bekerja secara elektronik. Pada tahun 2020, diperkirakan jumlah penonton esport di Indonesia akan terus berkembang hingga 14,3 juta orang. Berdasarkan pada data - data perkembangan E-sport khususnya game moba yang kini sangat ramai di gemari khususnya di Indonesia ini.Tujuan saya disini adalah di tujukan untuk para penggemar permainan game moba yang bisa di mainkan lewat komputer ataupun handphone, mereka mulai dari anak - anak hingga para pro player yang akan mendapatkan fasilitas khusus yang mana untuk saat ini yang sangat di sayangkannya belum ada fasilitas - fasilitas yang membantu mereka dengan baik. Dengan adanya proyek "E-sport Tournament dan pelatihan" yang akan di kelola oleh pemerintah serta badan swasta. Tempat untuk tournament sekala nasional, tempat pelatihan serta tempat edukasi khusus dengan harapan bisa semakin memajukan kota Jakarta ini , memberikan ruang untuk mata pencarian yang baru. 


\section{Permasalahan}

Pada Kota Jakarta merupakan kota yang padat. Dari kepadatan kota tersebut tentunya di imbangin dengan pertumbuhan populasi di kota Jakarta yang juga semakin meningkat pesat. Dari semakin padatnya penduduk di Jakarta ini, kehidupan mereka tak terlepas dengan pekerjaan yang lama - kelamaan membuat mereka membutuhkan sebuah tempat rekreasi, tempat wisata. Namun pada saat ini kebanyakan tempat wisata yang sudah memberikan kesan membosankan. Di era modern ini tengah berkembang salah satunya ialah "E-sport" yang mana tengah berkembang di seluruh dunia, namun di Indonesia, khususnya di kota Jakarta sendiri belum memiliki wadah tempat wisata E-Sport itu sendiri. Wadah E-Sport ini sendiri harus bisa memberikan kesan hitec pada fasad bangunan.

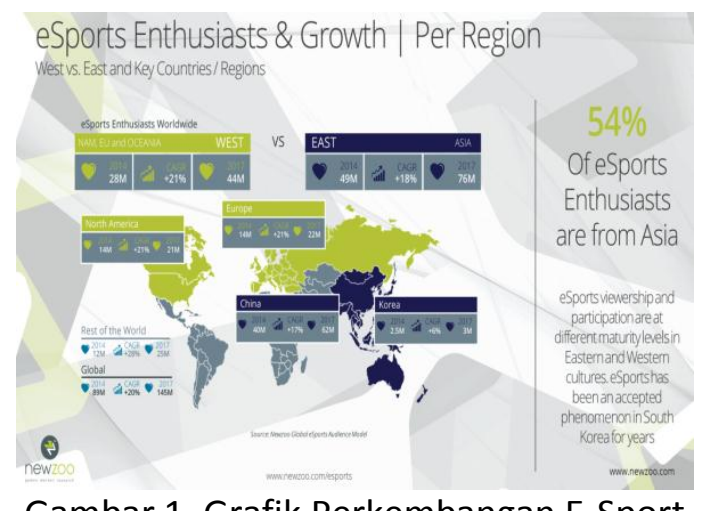

Gambar 1. Grafik Perkembangan E-Sport Sumber: Newzoo, 2018

\section{Tujuan}

Mampu memberikan sebuah wadah tempat wisata rekreasi E-sport yang tengah sangat berkembang saat ini, menjadi ada dikota Jakarta yang juga di harapkan dapat memberikan dampak pada lingkungan sekitar dan khususnya bisa menjadi icon baru pada kota Jakarta.

\section{METODE}

Perancangan dilakukan melalui metode kualitatif dengan teknik pengumpulan data dari studi literatur buku dan pencarian data melalui internet. Melakukan survei lapangan untuk mengetahui keadaan sekitar, program yang dibutuhkan, lokasi titik tapak yang layak digunakan. Menganalisis data-data yang telah diperoleh agar bisa menghasilkan program ruang, zoning, dan konsep massa yang baik.

\section{DISKUSI DAN HASIL}

E-Sport Turnamen yang berada pada jalan kebayoran baru ini memberikan sebuah wadah baru untuk para pecinta E-sport di tanah air khsusnya di Jakarta yang sebelumnya belum mempunyai wadah khusus seperti ini. Pada bangunan ini menyediakan tempat khusus untuk bertanding / turnamen dengan hadiah yang cukup besar yang bersekala lokal dan nasional, tak lupa di tunjang dengan program seperti game shop, restoran, gym, tempat pelatihan, yang harapkan bisa semakin membuat para pengunjung lebih nyaman dan menikmati wadah baru ini. 


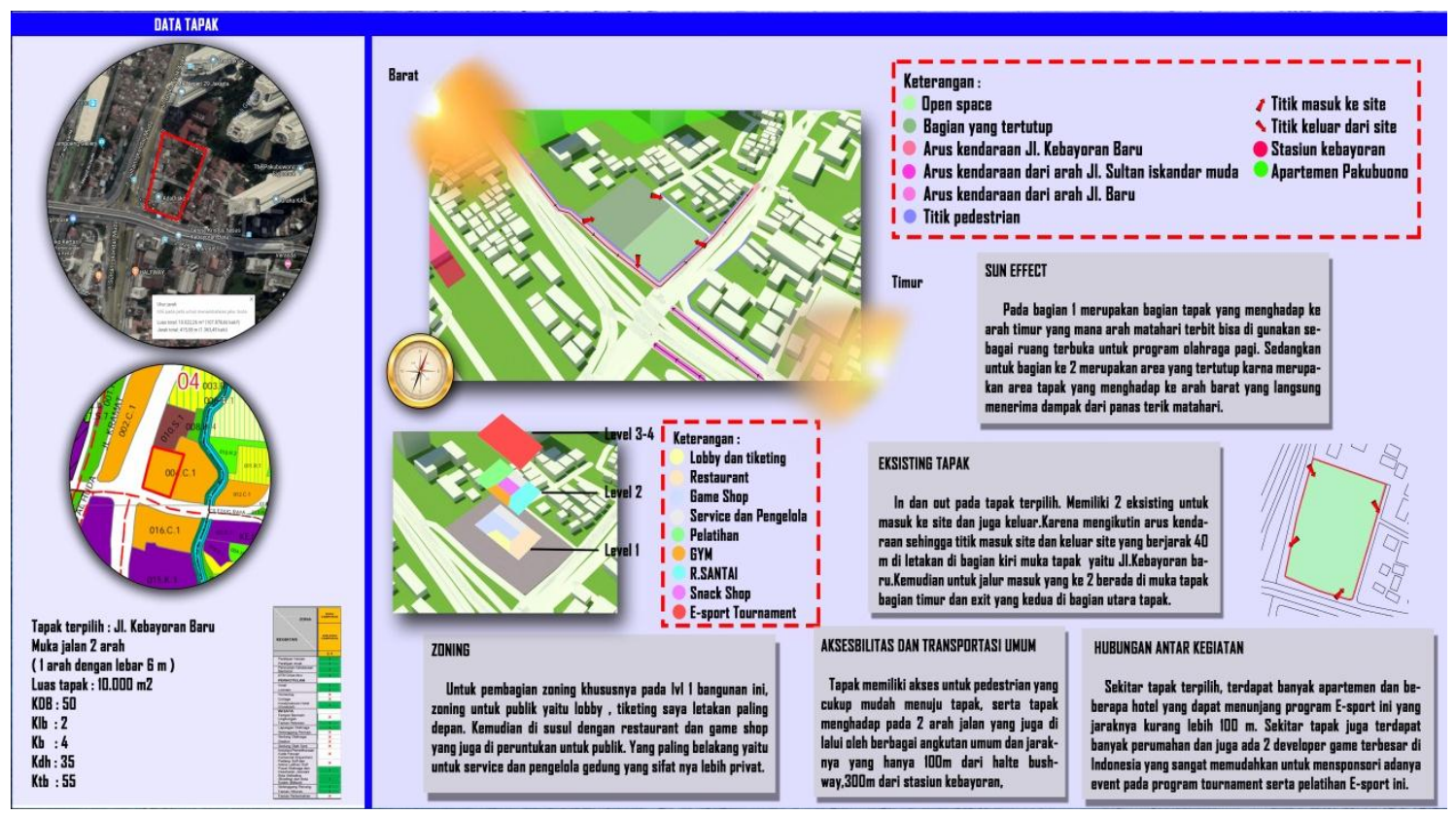

Gambar 2. Analisis Kebayoran Baru Sumber: Data Pribadi

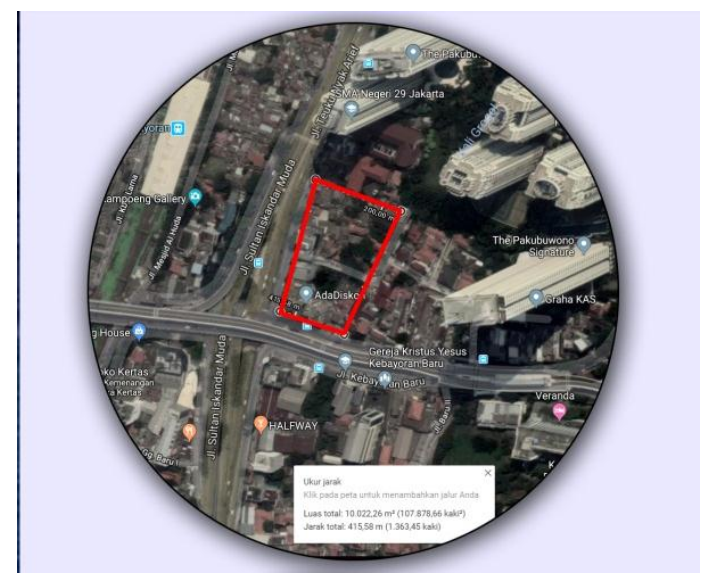

Gambar 3. Tapak

Sumber: Data Pribadi

Tapak untuk E-sport turnamen ini terletak di huk jalan yang langsung terlihat dari jalan jalan besar dan di kelilingin oleh banyak apartmen dan hotel - hotel di sekitarnya yang dapat menunjang akan program yang di adakan ataupun yang ingindi laksanakan di site atau bangunan tersebut. Dengan lokasi tapak yang seperti ini dan juga memiliki akses serta sarana transportasi umum yang mudah untuk menuju ke site di harapkan bisa berjalan dengan baik.

Mengapa masalah akses dan fasilitas sekitar disini ssangat di utamakan, karena program Esport turnamen ini di bukan untuk segala usia, dan di imbangin oleh sangat banyaknya yang tengah menggemari E-sport pada saat ini yang di pastikan sangat ramai orang yang ingin menuju ke site, sehingga di butuhkan akses yang mudah serta transportasi umum yang bisa dengan mudah mendapat akses ke site langsung. 


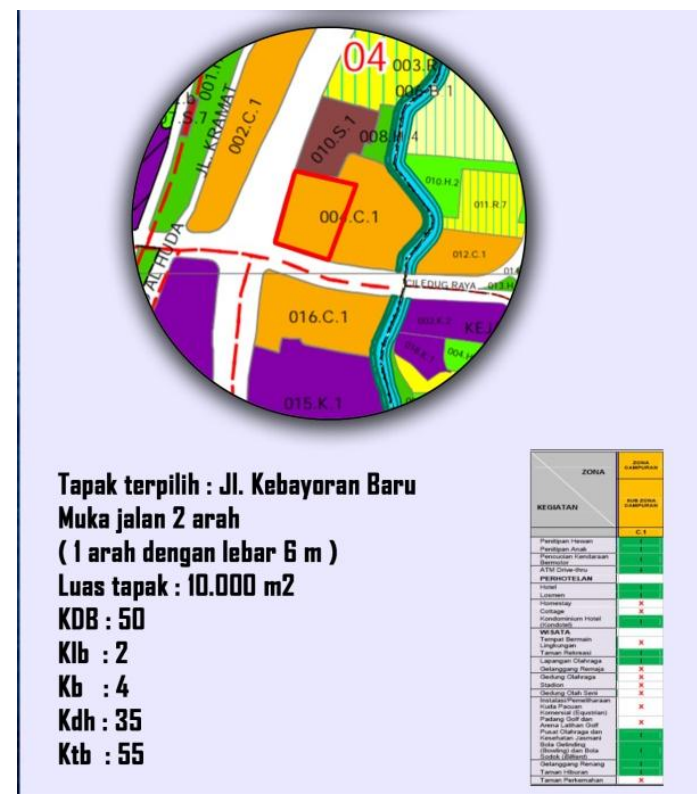

Gambar 4. Data Tapak Sumber: Data Pribadi

Adapun data - data dari site yang sudah melalui pertimbangan untuk di daerah situ di jadikan site bangunan E-sport turnamen. Yang merupakan zonasi campuran kemudia di kelilingi oleh zonasi ungu yang merupakan perkantoran dan beberapa zonasi kuning yang merupakan perumahan.Dari zonasi yang kita dapat berdasarkan data tersebut, di yakini bahwa cocok untuk di jadikan sebuah site E-Sport turnamen ini.

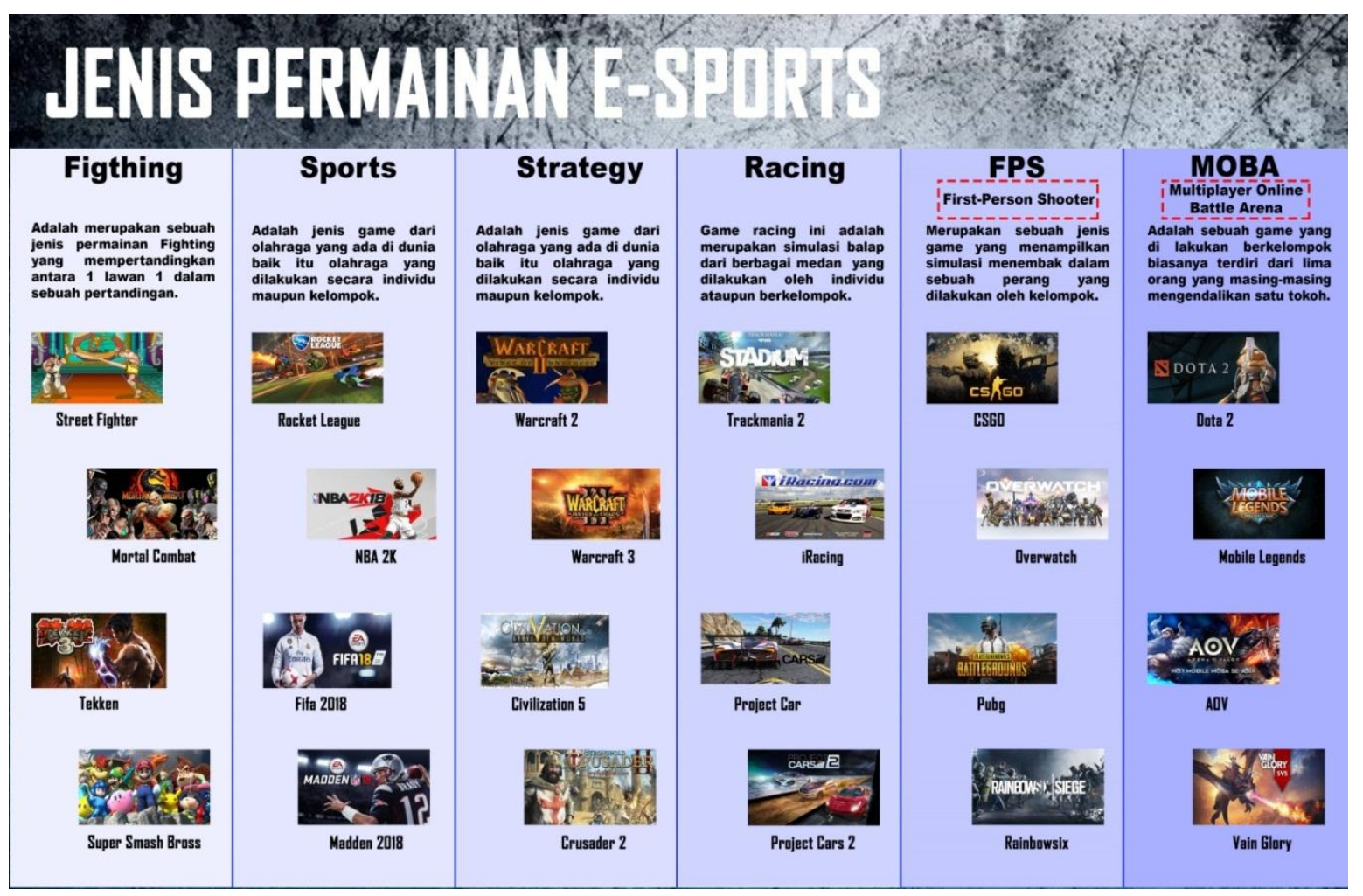

Gambar 5. Jenis Permain E-Sport Sumber: Data Pribadi

Dari berbagai jenis yang sudah di rangkum (Gambar 7). Untuk E-sport turnamen ini hanya 
memperlombakan FPS dan MOBA saja yang mana dari masing - masing itu terdari dari 5 buah game yang tentunya 5 game itu saat ini tengah ramai di gemari oleh seluruh penjuru dunia termasuk di Indonesia ini sendiri.

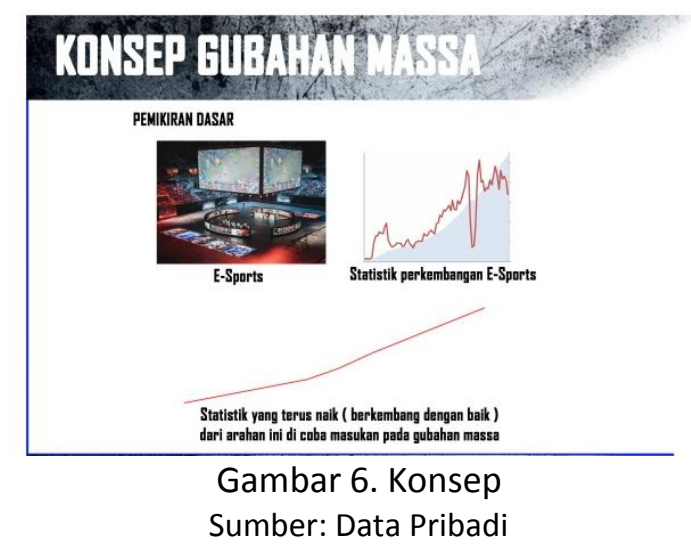

Dari konsep dasar untuk gubahan massa ini, saya terinsiprasi dari statistik pertumbuhan atau perkembangan E-sport yang saat ini tengah berkembang sangat pesat. Dari statistik itu sendiri cendrung menanjak dengan singnifikan. Garis garis yang mengarah naik itulah yang mendasari dari bentukan - bentukan pada gubahan massa saya yang penuh dengan corak atau garisan - garisan yang mencuat atau mengarah ke atas seperti layaknya statistik pada perkembangan E-sport yang saya telah dapatkan dan menjadi ide dasar tersebut.

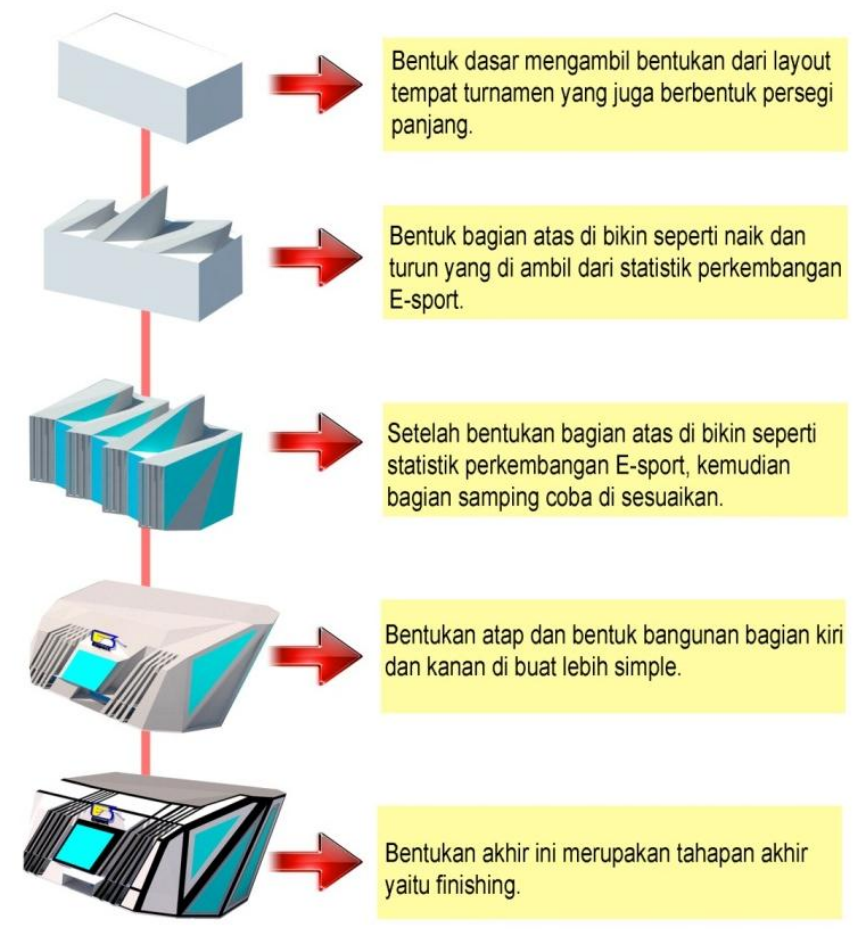

Gambar 7. Proses Gubahan Massa

Sumber: Data Pribadi 


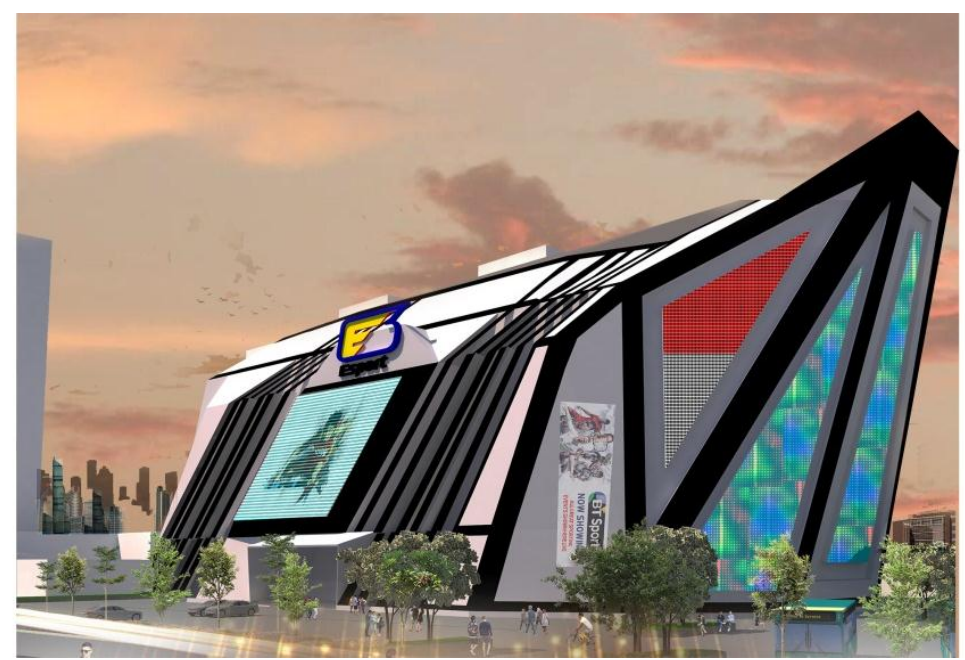

Gambar 8. Perspektif Eksterior Sumber: Data Pribadi

Sirkulasi kendaraan untuk keluar dari site untuk para pengguna bus / kendaraan pribadi yang menggunakan akses yang sama. Bisa setelah drop off langsung keluar lagi, atau mau langsung parkir dulu. Pada sirkulasi yang khusus pejalan kaki berapada pada bagian depan site langsung yaitung yang berhadapan langsung dengan Jl. Utama Kebayoran Baru, sehingga langsung dapat masuk ke gedung dengan mudah.

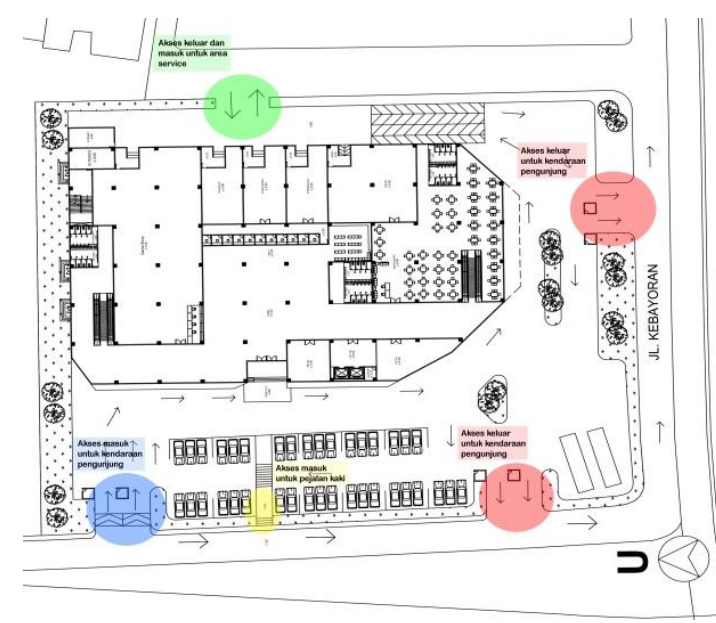

Gambar 9. Sirkulasi di Site

Sumber: Data Pribadi

Pada bagian service dan pengelola diletakkan pada bagian belakang karena lebih mudah dalam proses pengontrollan oleh karyawan dan tidak mengganggu area pengunjung. Dan pada penzoningan dibagi menjadi 7 bagian yaitu zona penerima (ruang lobby, ticketing), zona turnamen, zona pelatihan, zona pengelola, zona retail, zona Gym, dan zona service. 

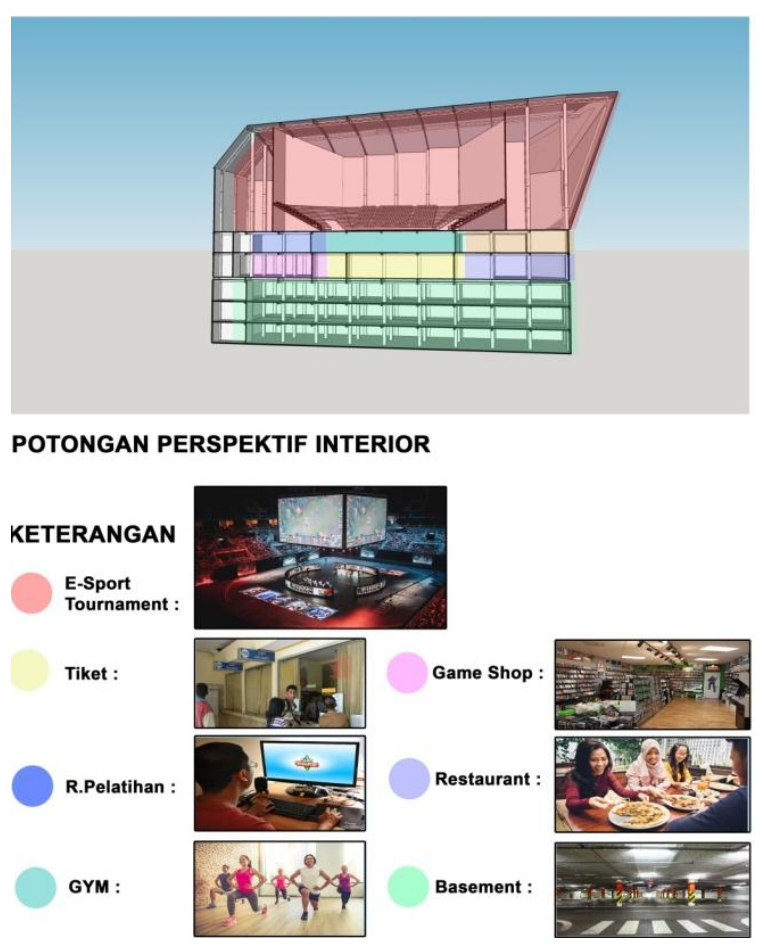

Gambar 10. Zoning Per Lantai Sumber: Data Pribadi

Pada perancangan dalam bangunan ini, terbagi atas 4 bagian yaitu lantai dasar untuk penerima, lobby, ticketing, retoran dan Game Shop. Sedangkan untuk lantai 2 merupakan tempat pelatihan dan lantai yang ke 3 yaitu tempat turnamennya. Sedangkan bagian 1 lagi yaitu untuk parkir dan service.

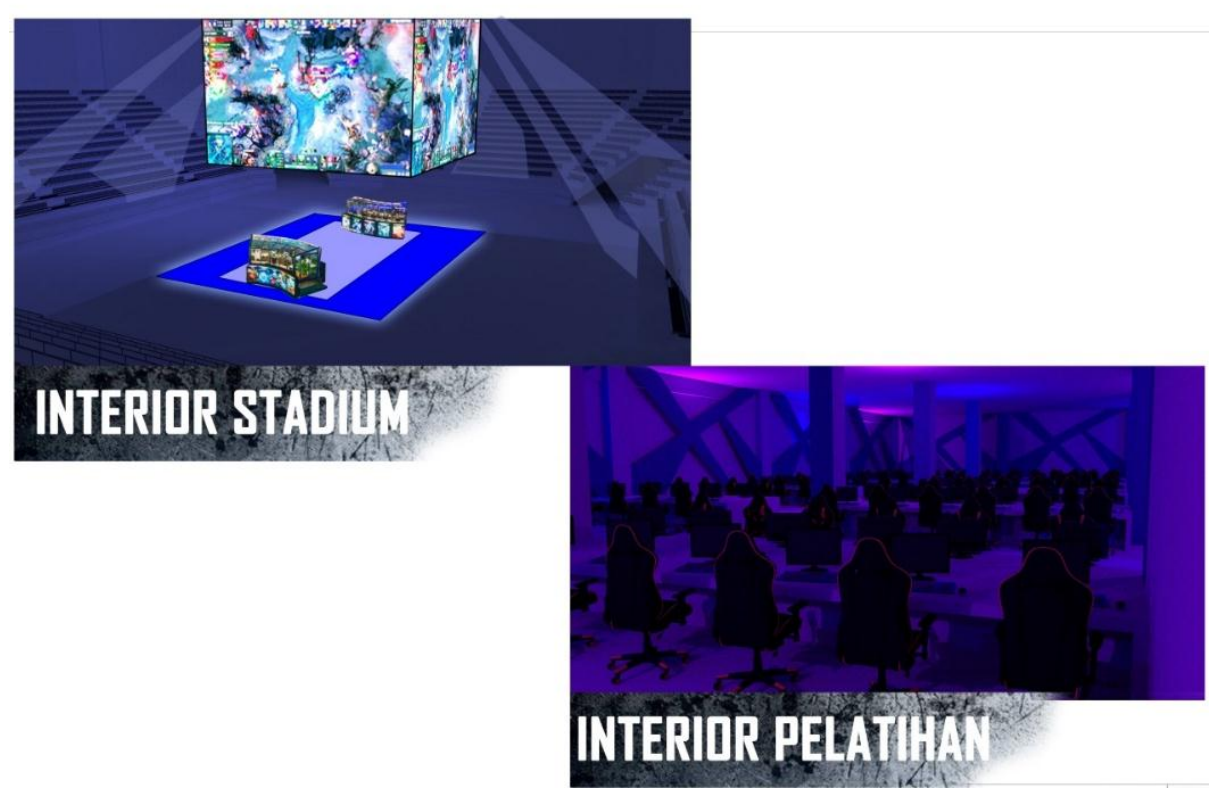

Gambar 11. Perspektif Interior Sumber: Data Pribadi

Pada bagian utama yang di tampilkan pada bangunan iyalah beberapa garis yang menjulang naik ke atas sesuai konsep dasarnya yang di lengkapi oleh LED. Pada bagian - bagian itu juga menggunakan bahan yang hi-tec seperti LED dan bahan ACP yang di harapkan memerikan kesan modern / hi-tec pada fasad bangunan ini. 


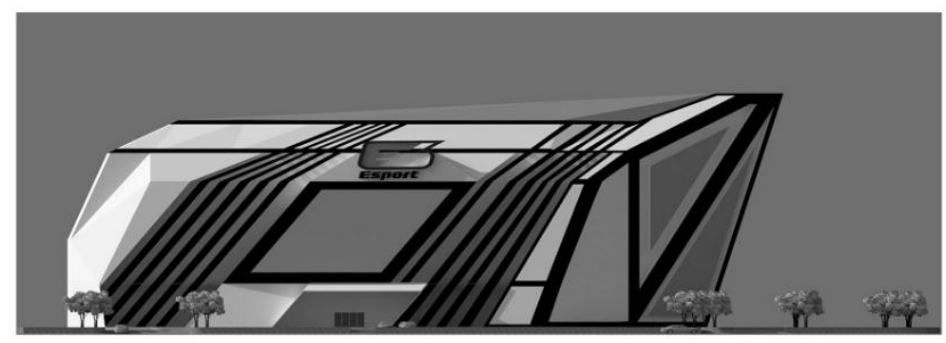

TAMPAK BARAT

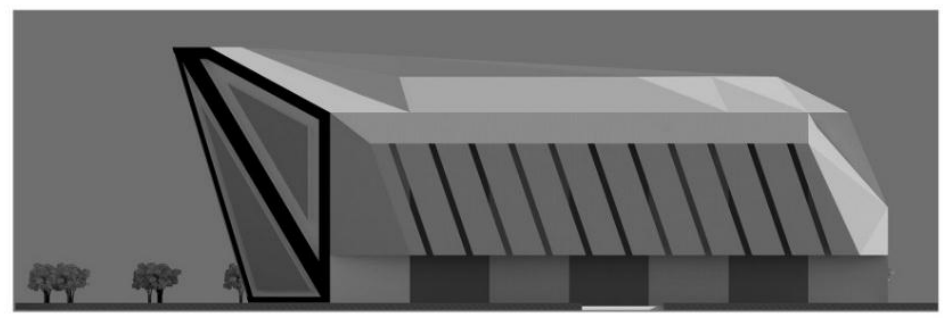

TAMPAK TIMUR

Gambar 12. Tampak

Sumber: Data Pribadi

Bagian kolom diberi pelapis penutup kolom untuk memberi kesan ekstetika. Struktur atap menggunakan struktur baja dengan bentangan lebar pada bagian tempat turnamen yang merupakan tempat ter-atas pada bangunan ini. Pada bagian fasad bangunan ini memiliki banyak LED, khususnya untuk bagian masuk ke bangunan dan beberapa lampu sorot yang biasanya di nyalakan pada saat malam hari. Sistem pengudaraan yang digunakan dalam bangunan adalah dengan sistem AC sentral untuk ruangan tournamaent, restoran, café, retail, gym , dan ruang pelatihan.

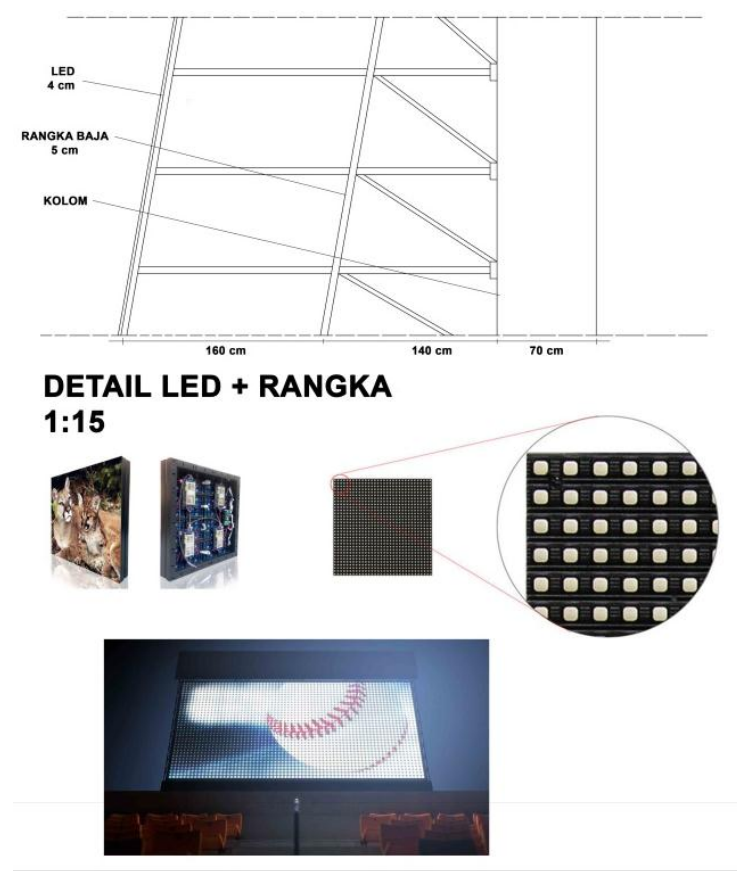

Gambar 13. Detail LED

Sumber: Data Pribadi 


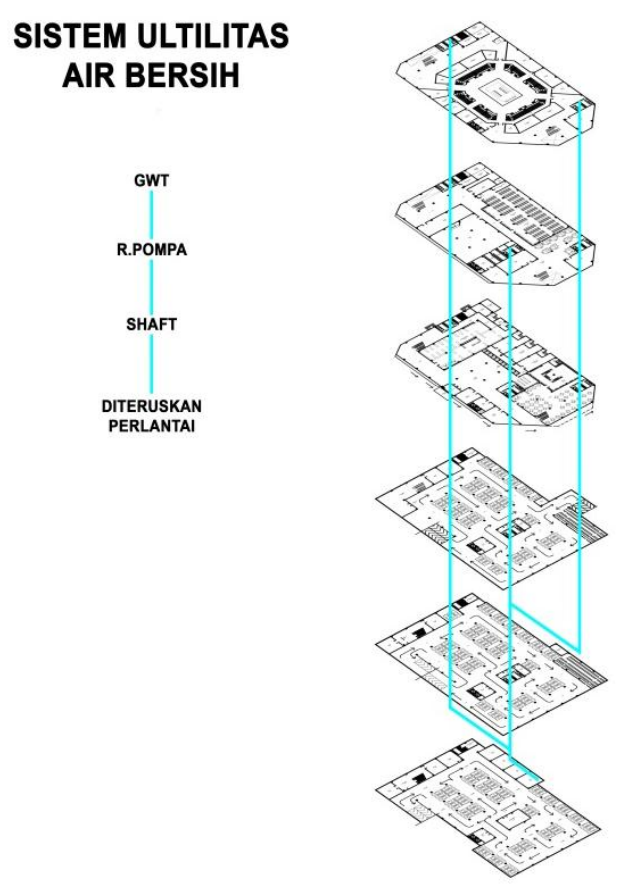

Gambar 14. Utilitas Air Bersih

Sumber: Data Pribadi

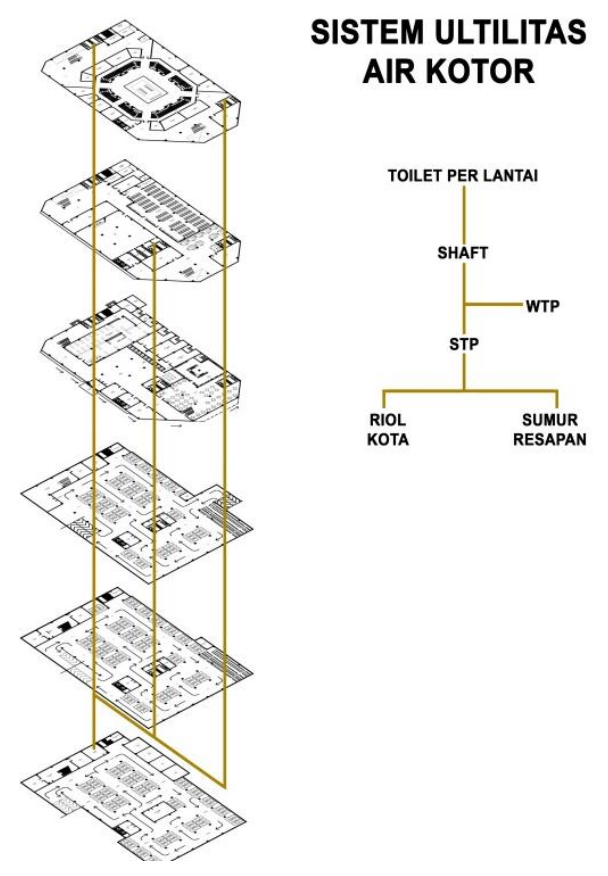

Gambar 15. Utilitas Air Kotor Sumber: Data Pribadi

\section{KESIMPULAN DAN SARAN}

Salah satu hal yang saat ini sangat berkembang di seluruh belahan dunia dan juga termasuk di Indonesia yaitu adalah E-sport. E-Sport yang saat ini tengah berkembang sangat pesat memberikan semua orang harapan baru di tengah - tengah sarana hiburan yang sudah mulai membuat jenuh khususnya di Indonesia. E-sport ini sendiri sangat bisa untuk dijadikan sebagai salah satu tempat wisata yang baru di Jakarta. Namun belum adanya wadah untuk E-sport ini sendiri sebagai tempat wisata yang baru. Karena itu, setelah di lakukan penelitian dan 
keinginan untuk membuat sebuah E-sport turnamen di Jakarta yang diharapkan dapat menjadi wadah baru untuk tempat wisata di Jakarta yang mana bisa di nikmati oleh semua kalangan dan usia mulai dari anak - anak sampai orang tua dan diharapkan dapat memberikan warna baru dari tempat rekreasi yang baru ini kepada pada seluruh masyarakat yang khususnya tinggal di Jakarta.

\section{REFERENSI}

Archdaily. (2009). 26 Oktober. Siauliai Arena / E. Miliuno studija + Dvieju Grupe Diperoleh 10 Agustus 2018, dari https://www.archdaily.com/

38742/siauliai-arena-e-miliuno-studija-dvieju-grupe

Archdaily. (2018). 29 Maret. Populous to Collaborate on Design of North America's First eSports Stadium

Diperoleh 12 Agustus 2018, dari https://www.archdaily.com/121226/institute-for-the-culinaryarts-hdr-architecture

Archdaily. (2018). 5 Juli. arlington-esports-arena. Diperoleh 14 Agustus 2018, dari https://www.archdaily.com/tag/arlington-esports-arena

Fitri, Firda. (2018). 22 September. Perkembangan E-sport di Indonesia setelah Asean Games. Diperoleh 22 Agustus 2018, dari http://www.tribunnews.com/techno/2018/09/22/makindiakui-sejak-asia-games-seperti-apa-perkembangan-esport-di-indonesia.

Kusuma, Wahyunanda. (2018). 25 Mei. Peluang dan tantangan industry E-sport di Indonesia. Diperoleh 9 Agustus 2018, dari https://tekno.kompas.com/read/2018/05/25/20170017/peluang-dan-tantangan-industri-esport-di-indonesia

Marcellino, Sandy. (2018). 3 November. Perkembangan E-sport yang semakin menjanjikan. Diperoleh 12 Agustus 2018, dari https://www.kompasiana.com/sandymarcellino/5bdd4399bde5757e4a1f5a89/perkemban gan-esport-yang-semakin-menjanjikan-di-indonesia.

Wisesa, Yoga. (2014). 19 Mei. Pemerintah konfirmasi dukungannya perkembangan E-sport di Indonesia. Diperoleh 14 Agustus 2018, dari https://dailysocial.id/post/pemerintahkonfirmasi-dukungannya-pada-perkembangan-esport-di-indonesia 